Revista Mídia e Cotidiano

ISSN: 2178-602X

Artigo Seção Temática

Volume 15, Número 2, maio/ago. de 2021

Submetido em: 11/01/2021

Aprovado em: 20/04/2021

\title{
A dimensão aurática das imagens-sonho no tarô e nas histórias em quadrinhos - estudo das tiras de Gasoline Alley ${ }^{1}$
}

\author{
Auratic dimension of dream-images in tarot and comics - a study of \\ Gasoline Alley strips
}

\section{La dimensión aurática de las imágenes-sueños en el tarot y los cómics - estudio de las tiras de Gasoline Alley}

\author{
Florence DRAVET ${ }^{2}$ \\ Ciro Inácio MARCONDES ${ }^{3}$
}

\begin{abstract}
Resumo
As imagens do tarô, assim como as dos quadrinhos, são arquetípicas e apelam para uma razão poética atuante nas brechas entre elas, convidando o leitor a constantes exercícios de montagens e remontagens narrativas. A partir dos estudos da imagem de Warburg e Didi-Huberman adentramos a poeticidade dessas imagens que consideramos imagenssonho dotadas de potência aurática imaginante. Também recorremos ao conceito de razão poética proposto por Zambrano. A análise de tiras Gasoline Alley, de Frank King, ampara nossa proposta. Concluímos que os saberes imagéticos do tarô baseiam-se em uma linguagem que ultrapassa códigos e sistemas de significação, estendendo seu alcance a uma potência latente, atuante na dimensão aurática das imagens-sonho. Dimensão também presente nas imagens dos quadrinhos, cuja teorização permite abrir-se a competências imaginativas.
\end{abstract}

Palavras-chave: Comunicação. Imagem. Imaginação. Poesia. Histórias em quadrinhos.

\begin{abstract}
The images of the tarot, as well as those of the comics, are archetypal and appeal to a poetic reason active in the gaps between them, inviting the reader to constant exercises of narrative montages and reassemblies. Based on the foundations of Warburg's and Didi-

\footnotetext{
${ }^{1}$ Trabalho apresentado ao Grupo de Trabalho Imagens e Imaginários Midiáticos do XXIX Encontro Anual da Compós, Universidade Federal de Mato Grosso do Sul, Campo Grande - MS, 23 a 25 de junho de 2020. Disponível em https://www.compos.org.br/anais_texto_por_gt.php?idEncontro=MzA=.

2 Professora do Programa de Pós-graduação em Comunicação da Universidade Católica de Brasília Mestrado Profissional Inovação em Comunicação e Economia Criativa. E-mail: flormd@gmail.com ORCID: 0000-0002-3822-3627.

${ }^{3}$ Professor do Programa de Pós-graduação em Comunicação da Universidade Católica de Brasília Mestrado Profissional Inovação em Comunicação e Economia Criativa. E-mail: ciroimarcondes@hotmail.com. ORCID: 0000-0002-1462-2260.
} 
Huberman's studies of image, we enter the poeticity of these images that we consider as dream-images, endowed with imaginative auratic power. We also resort to the concept of poetic reason proposed by Zambrano. The analysis of Frank King's Gasoline Alley strips supports our proposal. We have concluded that the knowledge of the tarot's images is based on an imaginary language that goes beyond codes and systems of meaning, extending its reach to a latent power, active in the auratic dimension of dream-images. This dimension is also present in the images of comics, whose theorization allows to open up to imaginative skills.

Keywords: Communication. Image. Imagination. Poetry. Comics.

\section{Resumen}

Las imágenes del tarot, así como las de los cómics, son arquetípicas y apelan a una razón poética activa en los huecos entre ellos, invitando al lector a ejercicios constantes de montajes y reensamblajes narrativos. Traemos los fundamentos de los estudios de la imagen de Warburg y Didi-Huberman para adentrarnos en la poeticidad de estas imágenes que consideramos como imágenes-sueños con poder aurático imaginativo. También recurrimos al concepto de razón poética propuesto por Zambrano. El análisis de las tiras Gasoline Alley de Frank King respalda nuestra propuesta. Concluimos que el conocimiento de las imágenes del tarot se basa en un lenguaje imaginario que va más allá de los códigos y sistemas de sentido, extendiendo su alcance a un poder latente, activo en la dimensión aurática de las imágenes oníricas. Dimensión también presente en las imágenes de los cómics, cuya teorización permite abrirse a habilidades imaginativas.

Palabras clave: Comunicación. Imagen. Imaginación. Poesía. Cómics.

\section{Introdução}

A história do tarô já é, em si, uma história onde a imaginação é matéria-prima para uma narrativa que se constrói em função de circunstâncias e conveniências. Em suas diversas versões, o jogo de cartas do tarô é um repositório de imagens que obedecem à dinâmica do próprio imaginário, tomado no sentido arquetípico, mítico e simbólico com todos os seus reflexos no âmbito cultural e social. As imagens ali apresentadas podem ser objeto de combinações e associações, aproximações, junções e disjunções que possibilitam ao intérprete a construção de narrativas também elaboradas em função de circunstâncias e conveniências. Ao mesmo tempo em que o tarô, para ser jogado, necessita da potencialização dos agenciamentos da imaginação e suas relações intrínsecas com as dimensões éticas, estéticas e poéticas da existência, o conjunto das 78 cartas do 


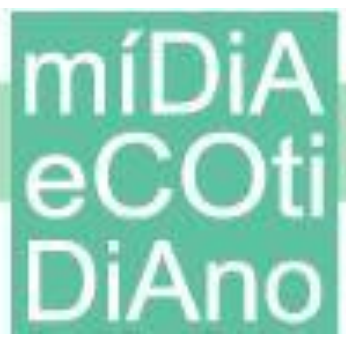

tarô pode ser uma potente ferramenta de desenvolvimento da atividade lúdica e imaginativa.

O intuito deste artigo é mostrar que as imagens - sejam elas midiáticas ou não possuem em si características de mobilidade, profundidade e multiplicidade e um caráter aurático que somente uma razão poética pode aferir ou expressar em sua dimensão onírica e fantasiosa. Partindo do conceito de razão poética (Zambrano, 1996) e da ideia de sabermovimento das imagens, tal qual proposto por Aby Warburg e explicado por DidiHuberman como espécie de saber-montagem, faremos uma aproximação entre as imagens do jogo de tarô e as dos quadrinhos, analisando parte da obra Gasoline Alley, de Frank King. Esta tira de jornal (subgênero narrativo para o medium das histórias em quadrinhos) estreou no Chicago Tribune ainda em 1918 e segue sendo publicada até hoje, muitas décadas após a morte do seu autor original (em 1969). Foi, durantes anos a fio, publicada em dois modelos: a tira diária (daily strip), em preto e branco, configurada em apenas uma "linha" de requadros; e a tira dominical (Sunday strip), colorida, que podia ocupar mais linhas e até uma página inteira, evidenciando o caráter tabular de determinados quadrinhos (conforme veremos), antecipando a estrutura do comic book norte-americano (a "revista em quadrinhos"). Ambas as estruturas, porém, continuam sendo tiras.

A partir dos anos 1930, King passou a experimentar mais nos arranjos visuais/narrativos das configurações das tiras dominicais, realizando experimentos com a temporalidade e a espacialidade delas, e ajudando a libertar um potencial de leitura e combinações de imagens pouco explorado antes no medium. Esta espécie de recombinação das formas de fazer sentido que os quadrinhos tinham até então funciona como uma iconologia de intervalos, conforme vamos discutir adiante, e encontra eco justamente na capacidade de reestruturação dos valores de leitura e associação mais livre de imagens dos jogos de tarô. A aproximação entre as duas formas de expressão se dá pela potência criativa das imagens em sequência impulsionadas por certa dimensão aurática que pretendemos resgatar. O exemplo de Gasoline Alley não é típico de todas as histórias em quadrinhos, mas serve de metonímia para a possível radicalização artística do medium como um todo.

Iniciaremos com uma reflexão sobre o caráter imaginário da história do jogo do tarô, entre jogo de cartas e método oracular e uma rápida explanação ilustrada da abertura 
metodológica do tarô ${ }^{4}$ a fim de introduzir uma proposta de sabedoria visual baseada na imaginação. Trataremos em seguida da razão poética como possível abordagem teórica para a potência imaginária das imagens não apenas do tarô, mas também das histórias em quadrinhos. Por fim, mostraremos em alguns exemplos de Gasoline Alley as semelhanças na linguagem que fazem de ambos - tarô e quadrinhos - sistemas de imagens-movimento ou imagens-sonho.

\title{
Tarô: uma história imaginada pela razão poética
}

O primeiro jogo semelhante ao tarô (isto é, com cartas representando os trunfos ou arcanos maiores, que se somam às do jogo de baralho comum) de que temos registro na Europa seria uma versão italiana de que se tem notícia por meio de uma missiva de 1449:

\begin{abstract}
A primeira dica intrigante sobre a identidade do inventor do tarô foi vislumbrada em uma carta escrita por um capitão militar veneziano, Jacopo Antonio Marcello. Datada de 1449, a carta vinha acompanhada de cartas de tarô como presente (carte de trionfi) destinado à rainha Isabel de Anjou, a consorte do rei René I, duque de Lorena. Marcello afirmou que o baralho havia sido pintado pelo famoso artista Michelino da Besozzo e inventado pelo duque Filippo Maria Visconti, de Milão. (FARLEY, 2009, p. 48, tradução nossa).
\end{abstract}

Não obstante dados arqueológicos que poderiam compor uma história objetiva do tarô, como proposta por Sosteric (2014), a história cultural do tarô, enquanto jogo e instrumento de adivinhação, é muito mais complexa. Envolve uma dimensão imaginária e imaginante, determinada por um contexto político, social e cultural que, na Europa do século XIX, estabeleceu fortes associações entre o tarô e os conhecimentos esotéricos egípcios. Segundo Sosteric, foi em função da necessidade de justificar uma moral impecável fundamentada em conhecimentos acessíveis a um grupo restrito de pessoas iniciadas que as sociedades secretas do século XIX se fortaleceram, erigindo-se em guardiãs de ensinamentos supostamente preservados sob a alcunha do segredo, do

\footnotetext{
${ }^{4}$ Para ilustrar tais explanações, o tarô utilizado aqui será o de Marselha (Restaurado por Jodorowsky e Camoin), por ser ele considerado a versão mais antiga ainda em circulação, embora saibamos que existem inúmeras versões do jogo cujo valor não está aqui em questão e que utilizam os mesmos métodos.
} 


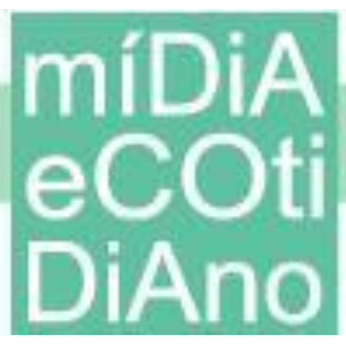

mistério e do hermetismo desde os tempos da sociedade egípcia faraônica. A origem egípcia atribuída ao tarô teria então servido para a construção de uma narrativa que teria transformado as cartas de jogar do tarô em instrumento mágico, de caráter divinatório.

O fato é que, no final do século XVIII e no decorrer do século XIX, paralelamente ao afastamento da Igreja Católica do poder político e ao desenvolvimento da ciência positivista, desenvolveu-se na Europa uma paraciência, por vezes chamada de esotérica, por vezes qualificada de pseudociência, que fundamentava seu conhecimento nos antigos mistérios e saberes ocultos. Foi a época em que Napoleão Bonaparte conquistou o Egito, levando consigo arqueólogos e cientistas que enviaram para a França muitos artefatos e peças da arte e do culto egípcio antigo. Também a Índia se tornou mais acessível não só para o comércio, mas igualmente para as trocas intelectuais que foram intensas nesse período, em especial com a Inglaterra. Foi nesse contexto, intelectualmente confuso e tumultuado, que o tarô esotérico fez sua aparição oficial. O pastor protestante e membro da maçonaria Antoine Court de Gébelin publicou em 1781 os oito volumes do livro Le monde primitif, dos quais constavam dois ensaios que expunham os significados místicos, cabalísticos, astrológicos e egípcios do tarô italiano do século XV.

Escrevendo sobre o tarô de Marselha especificamente, Alejandro Jodorowsky e Mariane Costa (2016) afirmam que não é possível atribuir a uma só pessoa e a nenhuma unidade de tempo e espaço a criação dessa versão do jogo de cartas, dada sua complexidade. Enfatizam que, por volta do ano 1000, na Espanha "era possível ver, em santa paz, erigidas muito próximas umas das outras, uma igreja, uma sinagoga e uma mesquita. As três religiões se respeitavam e os sábios de cada uma delas não hesitavam em discutir e enriquecer-se do contato com membros das outras" (Jodorowsky e Costa, 2016, p. 23). Desta forma, os autores explicam que nas cartas do jogo de tarô de Marselha - que pode ter recebido uma influência de artistas da Espanha - aparecem símbolos muçulmanos, hebraicos e cristãos.

Embora essas afirmações careçam de fundamentos objetivos que as legitimem enquanto dados científicos e embora pareçam baseadas em uma perspectiva um tanto idealista sobre uma possível coabitação tolerante entre culturas e religiões no ano 1000 na Europa, elas têm a vantagem de corresponderem a uma realidade talvez mais concreta para aqueles que manipulam as cartas de tarô, em uma atividade criativa e imaginante, do 
que os dados cientificamente comprovados da história escrita, de caráter elitista e classificatório. Importa destacar aqui que os saberes oraculares fundamentam-se no cruzamento entre duas episteme: "as formas visuais do saber e as formas sábias do ver" (Didi-Huberman, 2011, p. 13), precedendo a lógica aristotélica e colocando a imagem, contra qualquer possibilidade de pureza estética, no âmbito da multiplicidade, do diverso e do híbrido próprios à montagem.

Indo além dos aspectos históricos e formais da constituição do tarô e dos fundamentos de sua transformação em instrumento mágico oracular, vejamos as relações possíveis entre essas imagens arquetípicas, a percepção intuitiva e os sentidos imaginários. Pois que, sem dúvida, o princípio-motriz do conhecimento oracular é o da intuição e da imaginação. Sobre esta última Didi-Huberman escreve: "Palavra perigosa, qual seja (assim como o é a palavra imagem). Mas é preciso repetir com Goethe, Baudelaire ou Walter Benjamin que a Imaginação, por mais desconcertante que seja, não tem nada a ver com uma fantasia pessoal ou gratuita" (Didi-Huberman, 2011, p. 13) (tradução nossa). Trata-se de uma atividade vital para que sujeitos, grupos sociais e culturas mantenham viva sua capacidade criativa, inventiva e adaptativa. Mesmo nos mundos mais desencantados, encontram-se meios de exercer a atividade imaginante, uma vez que pouco lhe é necessário para sustentar sua potência.

\section{Potência lúdica e imaginária das imagens}

Durand (2004) já mostrou que, embora tenha havido no Ocidente um iconoclasmo que ele qualifica de "endêmico", as imagens e o imaginário resistiram e encontraram meios de se manifestar na arte, preservando sua potência significante, como atestam os sucessivos movimentos artísticos do Romantismo, Simbolismo e Surrealismo.

Para tratar dessa potência imaginante, começaremos com uma narrativa. Jodorowsky $^{5}$ (2016) conta o modo como, em 1993, conheceu Philippe Camoin, herdeiro da gráfica que, desde 1760, imprimia o famoso tarô de Marselha. O pai de Philippe

\footnotetext{
${ }^{5}$ Personagem polêmico da cultura e das artes contemporâneas, Jodorowsky, nascido em Tocopilla, no Chile, em 1929, radicado em Paris, é poeta, cineasta, escritor de quadrinhos e romances, mas também se autointitula psicomago. Faz amplo uso das cartas do tarô em suas atividades psicoterapêuticas e em suas criações artísticas. Sua famosa obra em quadrinhos $O$ Incal (1981-1988), ilustrada pelo artista francês Moebius, por exemplo, tematiza cada capítulo com um arcano maior do tarô.
} 


\section{míDiA

Camoin havia falecido em um acidente e o terreno da gráfica fora expropriado. O herdeiro então passou por uma crise profunda e se retirou do mundo, vivendo na antiga casa do pai, como um eremita, apenas na companhia de uma televisão cuja antena parabólica lhe dava acesso a centenas de canais. Narra Jodorowsky que o rapaz estabeleceu uma relação de intimidade tal com a televisão, que conseguia sentir o cheiro das pessoas que apareciam na tela, fazendo dela sua interlocutora. Quando se deparava com um problema difícil de resolver, consultava a TV. Apontava o controle remoto e apertava aleatoriamente, buscando nas imagens que então apareciam a resposta para seu problema. Certo dia, querendo saber como retomar a tradição familiar interrompida pela morte do pai, consultou a TV. Eis que apareceu na tela a imagem de Jodorowsky. Segundo a narrativa, isso teria acontecido três vezes, de forma que Philippe Camoin escreveu solicitando um encontro com o psicomago. Do encontro, nasceria uma versão restaurada do jogo de tarô, que voltaria a ser impresso pela família Camoin.

Essa narrativa não passaria de uma anedota se não fosse indicadora exatamente daquilo que nos interessa explorar, ainda que de maneira especulativa pois não há dado concreto suficiente para firmar uma proposta teórica a respeito do papel das imagens todas elas - numa provável comunicação oracular ${ }^{6}$. Esta última seria uma forma de comunicação que qualificamos de ampliada, ou seja, uma comunicação capaz de ir em direção a outros níveis de realidade (Nicolescu, 2009), que exigem uma certa abertura ao sensível (Maffesoli, 1998). Tal proposta exige uma abertura epistemológica em direção ao que Didi-Huberman (2011) chamou, retomando Nietzsche, de "gaio saber inquieto", e tem implicações éticas e estéticas que, ainda que no nível da especulação, podem ampliar também nossas perspectivas sobre a imagem. A comunicação ampliada, inclusive a oracular, implica em considerar como dignos de estudo não apenas os saberes da cultura midiática e da cultura pop, mas também daquilo que se convencionou chamar de mythos em contraponto ao logos, ambas noções gregas que se complementam para constituir a unidualidade fundamental da episteme. As duas noções opostas se completam uma vez

\footnotetext{
${ }^{6}$ Para um maior desenvolvimento dessa noção ver DRAVET, 2019.
} 


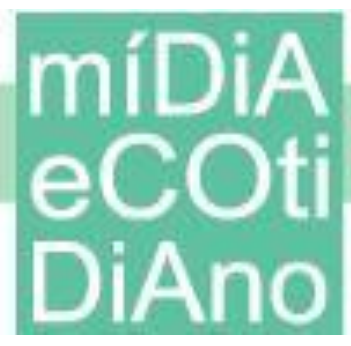

que a subjetividade, no interior do pensamento mítico, controla a exterioridade do pensamento lógico que lhe é necessário para impor seu poder sobre as coisas (Morin, 2010). Note-se que a atenção ao mythos não implica num retorno ao passado arcaico, mas uma postura contemporânea desviante, subversiva e por isso mesmo criativa, diante das imposições da lógica tecnocientífica.

Nessa perspectiva, assumimos, por enquanto, a sugestão de que as imagens podem integrar um corpo aglutinativo de impressões, conhecimento intuitivo e de formação de ideias que pode emergir de poços distintos de figurações que transformam, nas identidades culturais, sociais e individuais, os valores destas mesmas imagens (Warburg, 2010; Didi-Huberman, 2010, 2011, 2013).

No universo fechado sobre a própria interioridade do ermitão Philippe Camoin, cuja janela para o mundo exterior era uma tela de televisão, as imagens midiáticas se tornaram portadoras de mensagens suscetíveis de reconfigurar o sentido de sua existência. A atividade imaginante do leitor/receptor das imagens (as da razão poética, independente de seu suporte midiático e linguístico) torna-se aqui fundamental na criação do sentido que tais imagens potencialmente carregam em seu conteúdo simbólico. Poderia, portanto, um conjunto de imagens técnico-midiáticas como o da televisão funcionar como a organização narrativa e iconológica do jogo de tarô? Compreender o que ocorre com Philippe Camoin e Jodorowsky como reconfiguração de um imaginário que projeta uma leitura totalmente diversa dos códigos fornecidos pela própria realidade coincide com entender que certa razão logocêntrica derivada de Aristóteles e privilegiada pela filosofia moderna não comporta tais fenômenos.

A atividade lúdica embrionária estabelecida pelo jogo de tarô, ressignificada através dos séculos por meio de uma reapropriação, por parte de uma coletividade, de suas imagens, conflui em ideias como a de "razão poética", de María Zambrano (1996). A filósofa coloca certo "saber poético" na origem do comportamento humano, quando um mundo bruto de sentidos e percepções indefinidas da realidade se cindiu em dois caminhos possíveis de abordagem para a experiência: o primeiro, a "pergunta sem resposta", seria a razão logocêntrica e sua atitude de violência conceitual diante do mundo. A filosofia, em seu questionar tácito, brutalizaria a realidade. $\mathrm{O}$ segundo seria $\mathrm{o}$ 


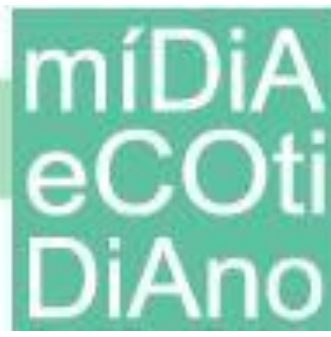

próprio saber ("razão”) poético, "resposta sem pergunta", um saber de reconciliação baseado na intuição e no incognoscível.

Este segundo saber proposto por Zambrano nos permite compreender a imaginação e uma frequência poética da percepção e da experiência como potências criadoras de realidades que se justificam na rica história "imaginária" do tarô e na intensa polivalência de suas imagens. Assim, o jogar no tarô, com sua análise combinatória e diversas formas de organizar sua disposição lúdica (ver Figura 1), funcionaria como princípio-motriz para a maneira como as próprias imagens da realidade (técnicas ou não) são postas no mundo. Além disso, o tarô ainda guarda ambivalência no que tange a seu caráter interpretativo, pois, assim como a poesia, ele pode ser pensado como essência (em seu caráter arquetípico) ou leitura (na decifração de seus signos). Era assim, por exemplo, que um teórico essencialista da literatura como Emil Staiger (1997, p. 21) via a própria poesia: algo originariamente uno que virava outra coisa ao ser segmentado por meio da interpretação. O saber poético, portanto, comportaria tanto a leitura e a narrativa, quanto a divinação.

Figura 1 - Exemplos de sistemas de disposição para jogo

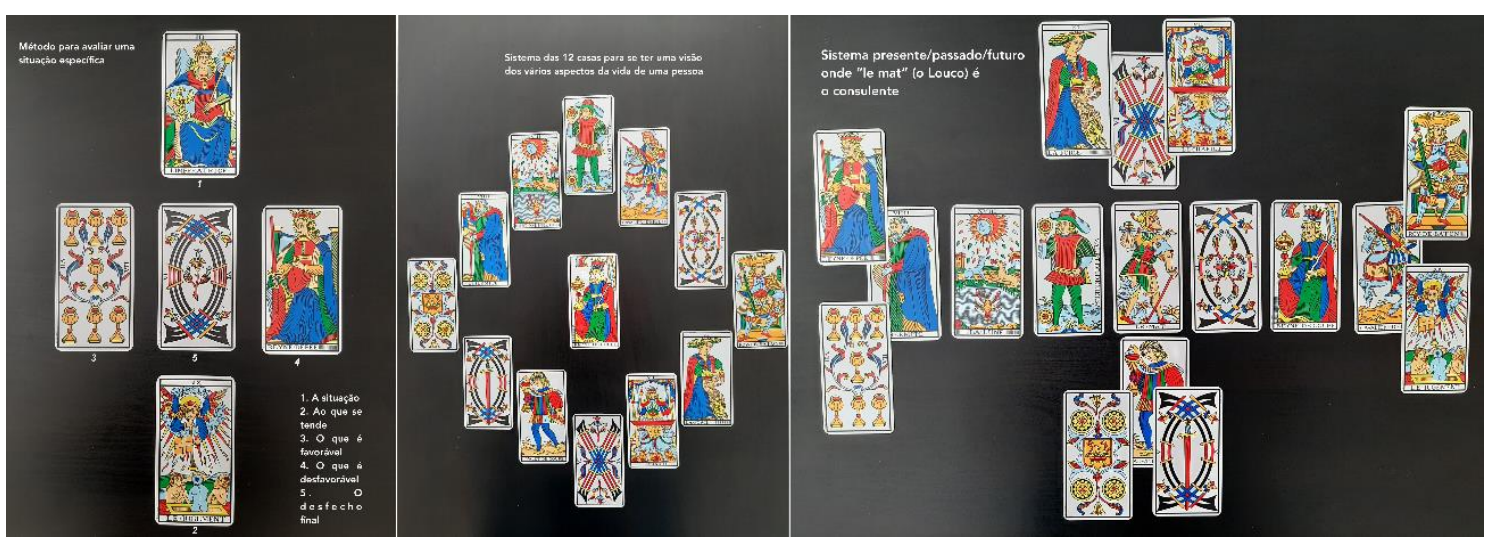

Fonte: arquivo pessoal dos autores.

Chegamos aqui às dimensões ética, estética e poética dessa ampla e problemática noção e suas relações intrínsecas com as imagens. No desencantado mundo weberiano (Weber, 2004), a verdade científica e o racionalismo despojaram a sensibilidade humana de sua capacidade perceptiva do invisível, do incerto e dos mistérios que, até ali, as religiões haviam se encarregado de explicar e controlar. No entanto, o indivíduo não cessa 
de sonhar e imaginar. Por mais desencantado que possa parecer seu mundo diurno objetivado, todas as noites, ele adormece e sonha, e de dia devaneia. Para Freud (1996, pp. 133-43), o devaneio diurno - quando nos perdemos imaginando coisas, relembrando momentos, criando linhas alternativas de realidade - tão frequentemente associado à poesia ou à loucura, é constituído exatamente da mesma matéria psíquica que os sonhos que nos visitam à noite. Mas que matéria psíquica é essa? Como ela altera nossa percepção do mundo, e como ela se manifesta nas imagens? A imagem-sonho em toda sua mobilidade e caráter difuso servirá aqui de referência para a atividade imaginativa investida na leitura do jogo de tarô e das histórias em quadrinhos que mostraremos a seguir.

O mundo das imagens em movimento é um mundo de potencial criativo em que ética, estética e poética não estão separadas umas das outras, mas são mutuamente implicadas e necessariamente investidas na ordem a ser encontrada para que ocorra qualquer narrativa. Chamamos aqui de imagens-sonho essas imagens em movimento: as imagens endógenas e exógenas (Belting, 2009), as técnicas, as mentais, as artísticas e as oníricas, desde que entendidas como pertencentes a um fluxo. Por mais estabilizadas e fixas que sejam, por meio das mais diversas linguagens, elas pertencem a um fluxo e uma desordem que aguardam um processo de seleção e combinação redundante em um sentido. Ora, o saber-movimento das imagens, tal qual proposto por Aby Warburg, é explicado por Didi-Huberman como saber-montagem, em que a capacidade de reordenação e análise combinatória implicam em um fluxo que seria, em si, o direcionamento (por vezes caótico, por vezes narrativo) que lhes traria sentido: "Sabermovimento das imagens, um saber em extensões, em relações associativas, em montagens sempre renovadas, e não mais um saber em linhas retas, em corpos fechados, em tipologias estáveis" (Didi-Huberman, 2013, p. 25). No extremo do movimento e do fluxo temos as imagens oníricas, e no extremo oposto as imagens científicas cuja pretensão é dizer apenas aquilo que se vê.

Didi-Huberman cita duas atitudes de esvaziamento das imagens, que lhes negam qualquer profundidade: a primeira é a do leitor tautológico que vê na imagem apenas aquilo que vê. Ficando "aquém da cisão aberta pelo que nos olha naquilo que vemos" (2010, p. 38), o sujeito pretende ater-se ao que é visto, postulando o resto como 
inexistente. Trata-se de "uma verdade rasa [...] lançada como anteparo a uma verdade subterrânea e bem mais temível” (idem, p.39), uma imagem cujo movimento é tornado estético. O leitor da crença, diferentemente, tem outro meio de "suturar a angústia" frente à "latência da imagem": ele supera a cisão aberta pela imagem e imagina algo totalmente diverso "tanto daquilo que vemos, como daquilo que nos olha", fazendo da experiência de ver "uma experiência de crença: uma verdade que não é nem rasa, nem profunda, mas que se dá enquanto verdade superlativa e invocante" (idem, p. 41), dando à imagem um sentido teleológico e metafísico.

As cartas do tarô possuem uma história e uma multiplicidade que atestam de sua riqueza simbólica e de seu potencial criativo flutuante e inesgotável. Trata-se de imagens que vemos, mas também que nos olham e refletem sobre nós seu conteúdo latente e angustiante (Didi-Huberman, 2010). Imagens auráticas, ainda em um sentido benjaminiano (que confere à imagem valor de culto), mas trazidas ao contexto da aparição ou acontecimento por Didi-Huberman. Stéphane Huchet, em sua apresentação do livro $O$ que vemos, o que nos olha esclarece:

A aura é um conceito (secularizado por Didi-Huberman) que procura dar conta da "dupla eficácia do volume: ser a distância e invadir" enquanto "forma presente", forma cujo impacto sustenta-se de latências que ela exprime. Entre aquele que olha e aquilo que é olhado, a distância aurática permite criar o espaçamento inerente ao seu encontro (HUCHET apud DIDI-HUBERMAN, 2010, p. 21-22).

Essa ideia de que a imagem aurática se exprime por meio de um "espaçamento inerente ao encontro" (de quem vê e daquilo que nos olha), criando fissuras nesta mesma imagem que permite que ela se distancie tanto da posição tautológica quanto da de crença, serve para pensarmos as funções intermediárias do tarô como conciliadoras entre tipos diversos de razão e de apreensão das imagens. A dinâmica de jogo, e, de certa maneira, de especulação como se em algoritmos, do tarô, permitiria que sínteses fossem formadas a partir das contingências do encontro entre a imagem-observante e o observador. Não à toa, de acordo com Sosteric (2014, p. 362), o famoso ocultista Aleister Crowley considerava o jogo como uma "gestalt cósmica à procura de expressão". 
Na maioria das vezes, o tarô é jogado a dois, sendo um aquele que faz perguntas ao jogo e outro aquele que manipula e interpreta as cartas. Ao utilizar um método específico de disposição das cartas (ver figura 1), pressupõe-se um valor para cada carta que servirá à elaboração da resposta pelo leitor do jogo. A interpretação se dá em função de uma poética inerente ao encontro entre os dois jogadores. Nesse sentido, as cartas são mediadoras, as imagens que elas apresentam adquirem sentido (arquetípico e simbólico) à medida do encontro.

Isso significa que, independentemente de qualquer valência oracular do jogo em si, a espessura simbólica do tarô, gerada nesta máquina aurática do encontro entre observador e imagem-observante, tem aspecto heurístico em relação a fabulações vagas situadas entre a tautologia e a crença. Trata-se de uma imagem-mediadora entre sonho e realidade, entre signo e referente, entre símbolo e coisa.

Do ponto de vista da razão poética, não há desencantamento possível diante desse tipo de imagem. O que pode haver é incompetência para a criação, passividade, letargia e fuga. Nesse sentido, o tarô pode ser uma ferramenta de desenvolvimento de competências imaginativas (o que vemos? O que nos olha?), assim como a narrativa dos quadrinhos, que convidam o leitor a uma atividade combinatória, baseada em intervalos, exigindo, ao mesmo tempo, da imagem e da imaginação.

\section{Imagens-sonho na HQ Gasoline Alley e nas cartas do tarô}

A história de Philippe Camoin e Jodorowsky sugere que os fenômenos plasmados nas imagens podem ser reordenados segundo certa "razão poética", por uma atitude criativa, desviante ou subversiva, que nos conduz a uma recriação imaginária do lugar destes mesmos fenômenos. Ao transportarmos a mesma iconologia do tarô para uma forma de arte narrativa como as histórias em quadrinhos, as pressões livres suscitadas pela razão poética se tornam ainda mais tangíveis, e o funcionamento imaginário do tarô como operacionalidade deste tipo de razão, menos abstrato.

O paradigma para a imagem, aqui, é o da imagem do sonho, tal qual concebida por Freud (2001), com seu deslocamento de sentido constante, como se, por trás de cada aparição em nossa vida fora da vigília, corresse um rio que modulasse o sentido em uma coisa nova. Por outro lado, há o arquétipo junguiano que, em seu atavismo, atribui à 


\section{eCOti
DiAno}

imagem um sentido identificável mesmo nos mais aleatórios contextos, conforme nos apresenta sua discípula Sallie Nichols (1995, p. 26):

Tais arquétipos funcionam na psique de maneira muito parecida com a que os instintos funcionam no corpo. Exatamente como um recémnascido chega com uma tendência inerente para mamar ou para assustar-se com um barulho forte, assim a sua psique mostra tendências hereditárias cujos efeitos podem ser observados de maneira semelhante. Está claro que não podemos ver essas forças arquetípicas, como, de fato, não podemos ver os instintos; mas experimentamo-las em nossos sonhos, visões e pensamentos de vigília onde aparecem como imagens.

Este movimento do sonho em direção às imagens que poderiam, portanto, ser moduláveis ou arquetípicas, seguindo a força selvagem de uma frequência poética da percepção, se coaduna perfeitamente com o modo livre de criação para as narrativas em um jogo de tarô. Este, em princípio, não possui regras fixas e mesmo aqueles modelos tradicionais de jogar podem ser subvertidos de acordo com a própria intuição do tarólogo e do consulente, transformando o processo todo em um eterno devir de reinvenção imaginativa. Jung considerava o arquétipo como um "sistema de virtualidades cuja conversão em símbolos tem origem no inconsciente" (Durand, 1964, p. 61). Sintonizar a percepção no âmbito da razão poética significa transitar em narrativas possíveis para a imaginação, e costurar um alinhamento distinto (por vezes irracional ou "noturno") para fenômenos e acontecimentos. Ora, a carta do tarô, enquanto não é virada, existe apenas enquanto potencialidade. A leitura por parte do tarólogo deve necessariamente ser intuitiva, e mesmo a narrativa formada conjuntamente por tarólogo e consulente só pode ser formalizada dentro de algum tipo de hermenêutica no momento em que o jogo é "tirado". Nesse sentido, um jogo como este funciona como uma história em quadrinhos cuja ordem de leitura pode ser reinventada com cada novo leitor, e o lugar das imagens se serve do diálogo entre proposições arquetípicas e sentidos móveis. De fato, há vários quadrinhos que subvertem a ordem de leitura e propõem associações entre imagens que podem quebrar a tradicional "linearidade" do medium ou mesmo propor uma iconologia aleatória.

As histórias em quadrinhos também podem se adaptar a estas condições de razão poética que são visíveis nos procedimentos do tarô. Não se pode esquecer que o aspecto 


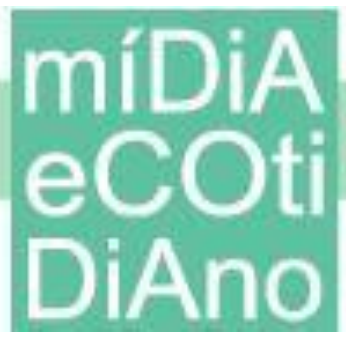

caricatural e, de certa forma, selvagem dessa mídia permite que, desde os seus primórdios, a vazão ao sonho e à fantasia tenha se tornado uma tônica dominante. Em sua forma moderna, que surge em meados do século XIX (ou seja, no mesmo período em que as cartas do tarô deixam de ser apenas um jogo para o divertimento e ganham funções oraculares), os quadrinhos sempre apresentam caráter deformativo, exagerado, onírico. ${ }^{7}$ As primeiras comic strips - pois os quadrinhos foram publicados apenas como tiras de jornal no mundo inteiro até o final dos anos 1930 - apresentavam personagens que tomavam a forma de crianças endiabradas (Yellow Kid, Buster Brown, Katzenjammer Kids), animais falantes (Mickey Mouse, Felix the Cat), quando não eram simplesmente surrealistas em sua totalidade (Little Nemo in Slumberland) ou mistura de todas as coisas anteriores (Krazy Kat). Nos Estados Unidos, essas tiras eram publicadas em grandes tabloides que dominavam o ambiente midiático das primeiras décadas do século XX (como New York Journal e New York World), e eram enormemente populares, especialmente as Sunday strips, publicadas coloridas, em uma página inteira, aos domingos.

Se os quadrinhos foram se modernizando e sofisticando suas proposições narrativas ao longo do século XX, chegando até às hoje prestigiadas graphic novels, neste início, quando as condições de produção eram modestas e havia pouco ou nenhum reconhecimento deste material como forma de arte, havia no entanto o frescor do terreno inexplorado, da imaginação plena, da criação sem rédeas. É dentro deste contexto (ainda que fosse, em geral, um quadrinho sobre os modos de vida americanos na primeira metade do século XX), que se localiza a tira Gasoline Alley, que será nosso objeto de aproximação com o tarô, dentro de uma iconologia na qual prevalecem estruturas de linguagem que também resvalam no conhecimento gerado pela razão poética.

Em geral, a arte dos quadrinhos narrativamente pode se concentrar nos intervalos entre os quadros (“sarjetas', tal qual proposto por McCloud [2005]), na relação entre a página ("tabular") e a linha (“linear"), tal qual proposto por Fresnault-Deruelle (1977), ou, pensando de maneira mais geral, em uma “solidariedade icônica” (Groensteen, 2007),

\footnotetext{
${ }^{7}$ Para uma discussão teórica a respeito da origem dos quadrinhos, ver Campos (2015).
} 


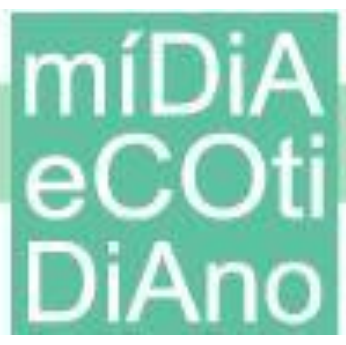

ou seja, em uma codependência irrestrita entre os quadros para que o medium exista em suas não tão singulares contingências.

Com o cinema, os quadrinhos compartilham características de uma narratividade editorial. Possuem uma instância meganarrativa, geralmente um começo e um fim, mudanças de tempo e espaço etc. (Gaudreault; Jost, 2009). Porém, há uma diferença substancial entre como tempo e espaço são modulados a partir dos materiais de expressão dos dois media. O cinema possui uma cronografia, ou seja, é escrito pela passagem do tempo (que muitas vezes é impulsionada pelo som, também tecnicamente ausente dos quadrinhos). Portanto, as mudanças de espaço cinematográficas são dirigidas pelo avançar do tempo. Nos quadrinhos, ao contrário, a temporalidade é dada pela modulação do espaço e não do tempo (que é ausente). É a imagem, em toda a sua polissemia, que emula a temporalidade de uma HQ e a dota de expressividade própria. O tamanho dos requadros, sua posição e formato, com valor semântico, ajudam a determinar a existência do tempo, sua precisão ou imprecisão e, como em um jogo de tarô, é a organização destes quadros/cartas dentro de uma "solidariedade icônica" que permite a transformação de valor sígnico/simbólico. É verdade que a montagem do filme também ajuda a determinar este tipo de relação no cinema, mas aí é importante ressaltar a imposição necessariamente linear e temporal. Nos quadrinhos e no tarô, a configuração do espaço é tabular, ou seja, constitui uma página (quase sempre) ou um jogo posto na mesa. Embora haja um fio narrativo conectando uma página à outra (em uma revista em quadrinhos) e eventualmente uma disposição e outra (no tarô), na leitura da imagem-sonho proposta aqui, é o que se apresenta ao olho que interessa interpretar dentro do princípio de "solidariedade icônica".

Vejamos o caso de Gasoline Alley. Esta tira, criada pelo cartunista (filho de um mecânico) Frank King ainda em 1918, tornou-se popular primeiro por discutir o então nascente mundo dos fanáticos por automóveis para depois se transformar em uma singela narrativa continuada sobre um pai ("uncle” Walt Wallet) e seu filho adotivo (Skeezyx), centrada fortemente nas idiossincrasias da classe média americana nas primeiras décadas do século XX. O tema pode parecer banal ou até conservador, mas essa tira lançou um olhar atento e microscópico sobre as antinomias do american way of life e seus contextos psicológicos, sociais, econômicos e até diplomáticos. A tira foi a primeira das HQs a 


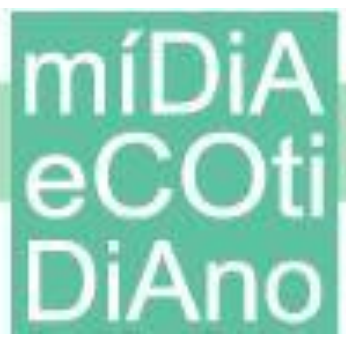

PPGMC

envelhecer seus personagens exatamente tal qual o tempo passa no mundo real, e é a mais longeva family strip americana a ainda ser publicada.

A despeito do caráter inovador da tira e de eventuais momentos de sofisticação artística, até os anos 1930 Gasoline Alley era basicamente um longo folhetim sobre famílias, publicado em preto e branco em forma de daily strips (as tiras simples de uma linha, que saíam diariamente - Figura 2). Porém, no final dos anos 1920 e começo dos anos 1930, King resolveu (conforme anunciamos no início deste artigo) realizar algumas Sunday strips (coloridas, de página inteira, em formato tabloide - vale ressaltar que esse formato, muito comum nos jornais americanos das primeira décadas do século XX, não era exclusivo de King) que trabalhassem especialmente o caráter tabular dos quadrinhos (conforme explicado acima), e sua "solidariedade icônica", trazendo para aquelas imagens um registro que cada vez mais iria se assemelhar tanto a uma iconologia de intervalos (WARBURG, 2010) quanto a esse desarranjo interno das imagens provocado pelo movimento inerente a todas elas.

Figura 2 - Gasoline Alley (daily strip)

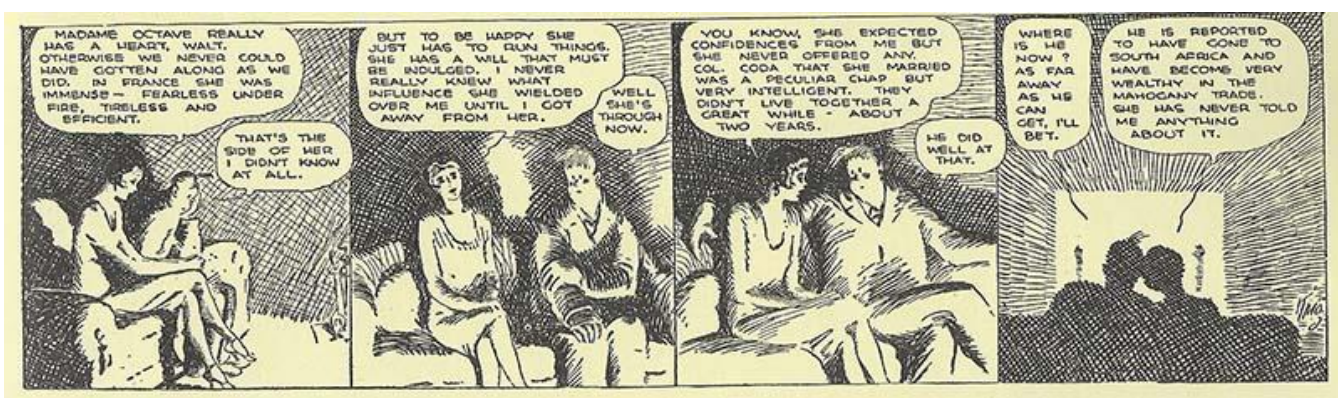

Fonte: King (2010).

Essas novas tiras introduzem fortemente a metalinguagem na elaboração de Gasoline Alley. Em uma delas (Figura 3), de 1930, por exemplo, Walt e Skeezyx se reconhecem como estando desenhados no "velho estilo das xilogravuras", e a tira se desenrola com os personagens pulando, de quadro em quadro, por diversos cenários onde as árvores e a madeira aparecem em diferentes circunstâncias, enquanto pai e filho travam curioso diálogo sobre como o húmus da terra é capaz de reviver as árvores que morreram, promovendo o ciclo da vida, e especialmente questionando de que forma a natureza seria capaz de saber a ordem e composição de todas as suas etapas. 
Figura 3 - Gasoline Alley (Sunday strip, 1930)
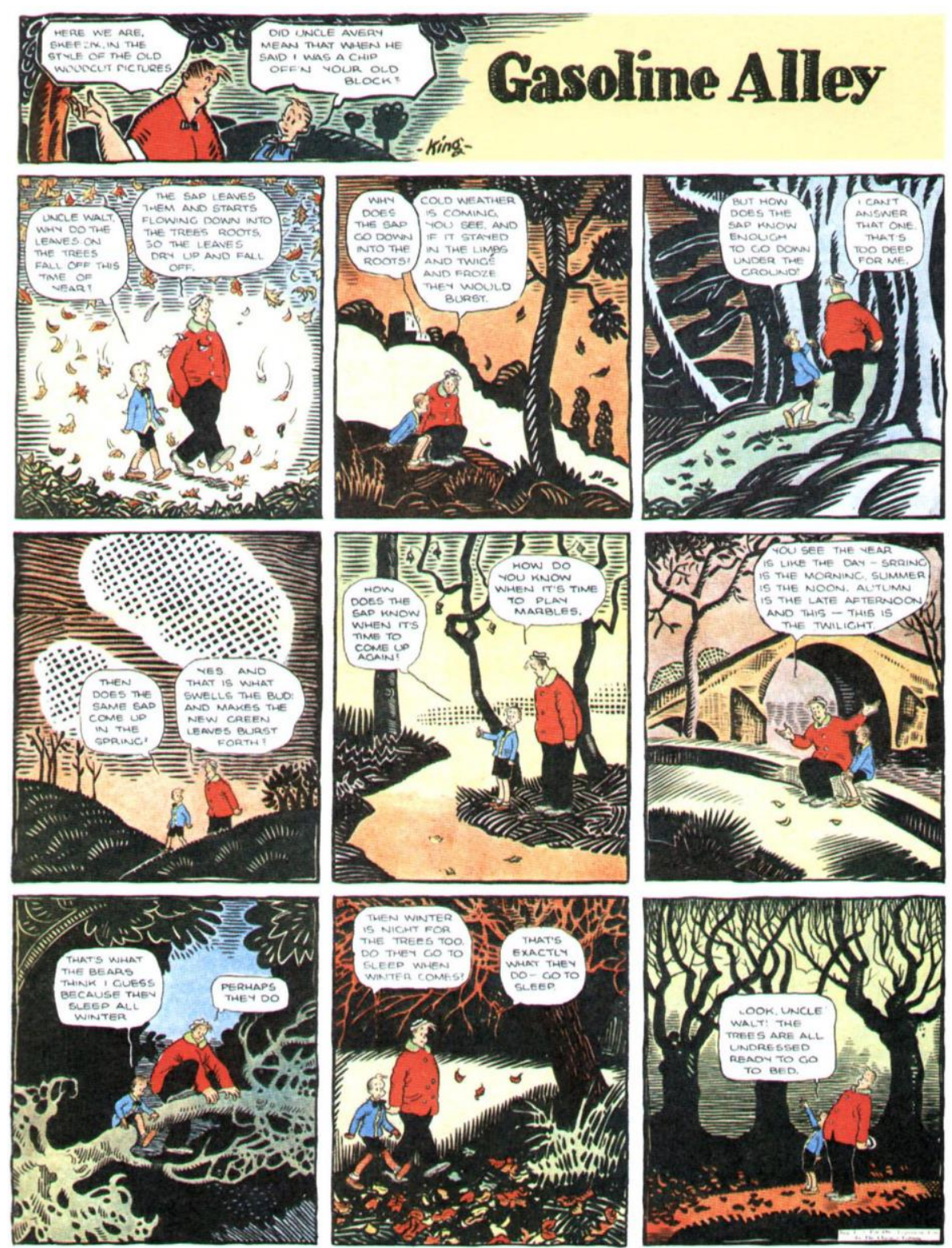

Fonte: Blackbeard e Williams (1977).

Frank King desenha a tira como se fossem as então "velhas gravuras" de madeira expressionistas, e a narrativa não possui um controle preciso sobre a passagem do tempo. São apenas pai e filho caminhando "por dentro" do próprio assunto sobre o qual discursam, relegando ao leitor uma temporalidade difusa, sem propriamente constituir uma diegese crível, com o tempo se situando na abstração filosófica do texto, mas também com cada imagem do quadro guardando um valor autônomo para si, como se fosse um momento isolado de reflexão, que se completa na solidariedade da tira completa. Isso se 


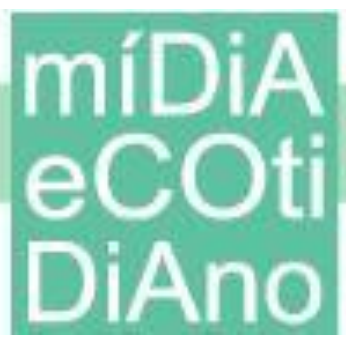

assemelha ao jogo de tarô, em que cada casa possui também uma valência própria (por exemplo, uma casa que represente o presente do consulente, ou outra que represente seus anseios futuros). Porém, o jogo só ganha efetivo sentido quando estes espaços particulares (as casas) se relacionam com os outros, permitindo uma leitura que transcenda, como um conjunto de mônadas, o significado individual de cada casa. É extremamente importante compreender que a leitura do tarô ocorre na relação narrativa entre as cartas, tanto na ordem posta pelo modelo de jogo, como em outras ordens quaisquer que podem surgir de acordo com a intuição de tarólogo e consulente.

Desta forma, o tarô permite, por meio de formações relacionais que não obedecem a uma linearidade, infinitas combinações possíveis de leitura para os jogos, que, sendo verdade ou não, inscrevem essas narrativas sobre os fenômenos requisitados pelo consulente. Nos quadrinhos, ainda que existam elementos narrativos característicos da mídia que conduzam a uma leitura mais unívoca (drive, following, framing, nos termos de Altman [2008]), essa erosão de uma temporalidade dada permite que nos situemos em um espaço fluido, imaginativo, de constante metamorfose, tal qual nas areias movediças do sonho na concepção freudiana, ou no saber-movimento proposto do Didi-Huberman.

Em procedimento semelhante, em uma tira de 1930 (Figura 4), Walt e Skeezyx estão no museu e tio/pai declara, olhando para um quadro que se assemelha a uma paisagem expressionista pintada por um primeiro Kandinsky: “O modernismo é um pouco demais pra mim. Eu odiaria viver no lugar em que esse quadro foi pintado" (tradução nossa). Diante do entusiasmo do menino para entrarem naquele mundo, porém, ambos decidem ir em frente e, de maneira surrealista, passam a visitar, de corpo e alma, as paisagens das pinturas. Nos requadros seguintes, os personagens estão literalmente caminhando dentro de pinturas ditas "modernistas" (há uma paisagem aquática no estilo impressionista de Monet; há um macaco com suas formas decompostas no estilo cubista, etc.), ficando zonzos e enjoados diante da realidade turva das formas deste tipo de arte. No último requadro, eles veem uma luz no horizonte e passam a se sentir aliviados, percebendo que estão saindo do "mundo das pinturas". Skeezyx afirma: "Este foi um sonho horrível, tio Walt. Ou será que foi mesmo um sonho?” (tradução nossa). Na imagem, no entanto, vemos que os personagens não apenas não saíram do mundo das pinturas, como começam a se mesclar com elas, transformando-se em rastros de arco-íris. 
Figura 4 - Gasoline Alley (Sunday strip, 1930)
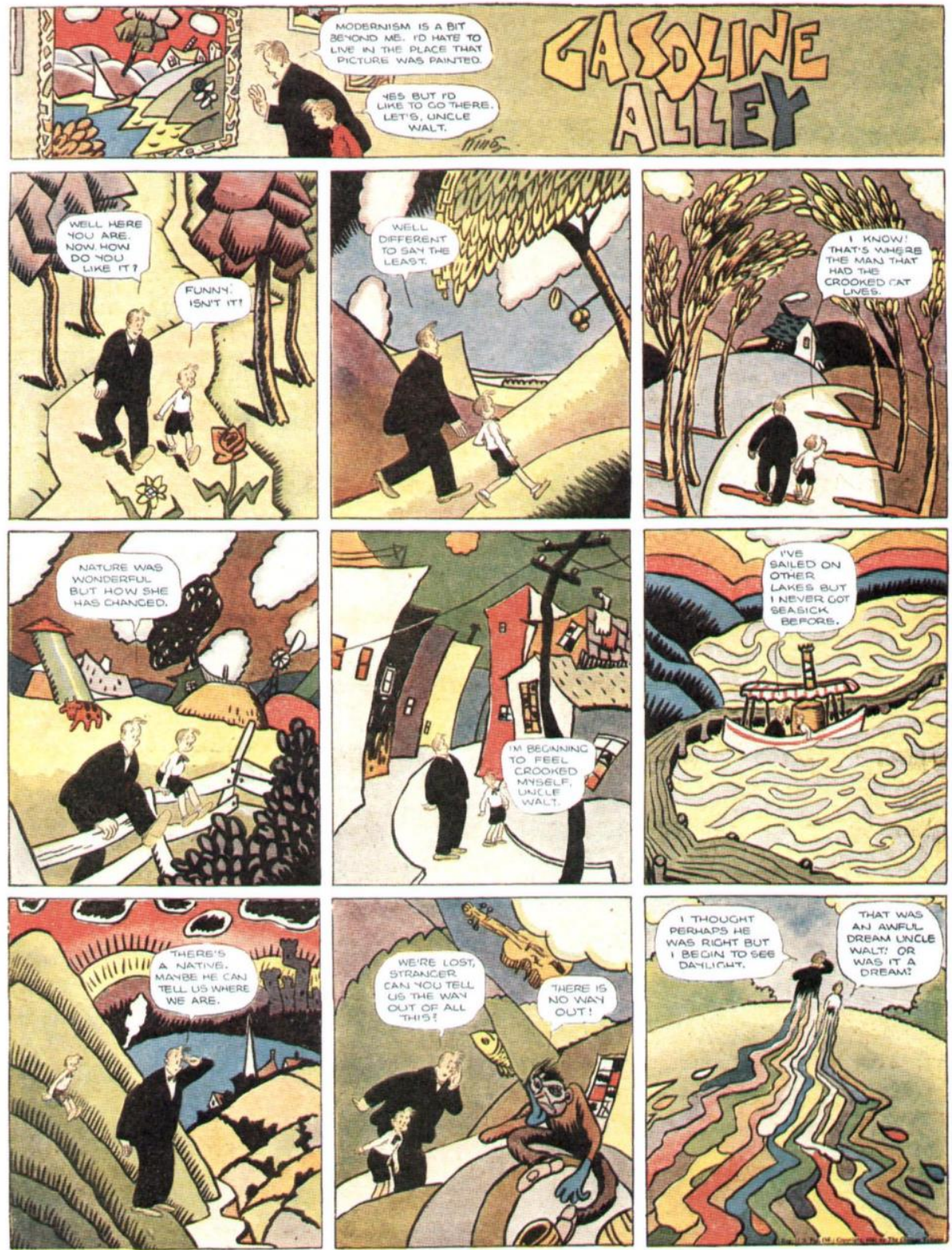

Fonte: Blackbeard e Williams (1977).

Também nessa tira, a composição cromática, tabular, da página (além de seu forte aspecto metalinguístico), permite que essas imagens se tornem um corpo, tal qual pensado por Didi-Huberman; que elas nos olhem de volta, reconfiguradas, em seu seus diversos sentidos, pelas também diversas potências que se lhes emanam: a ordem e o significado relacional dos quadros, as referências internas, a consciência dos personagens sobre sua própria condição de personagens, o aspecto labiríntico que a tira assume e a própria 


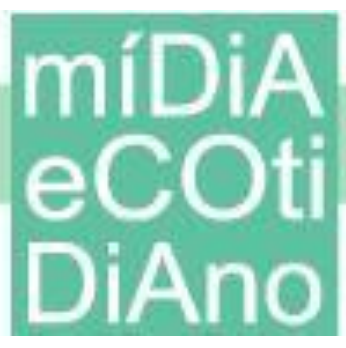

assunção de que, quando um conteúdo imagético se encontra sintonizado em uma frequência poética, torna-se difícil determinar a fronteira entre o lugar do real e o da imaginação, considerando que os fenômenos da realidade podem ser reinventados de acordo com a lógica deslizante da imagem-sonho. Que os personagens, no final das contas, se diluam na própria tira, é um sintoma destas relações.

Figura 5 - Gasoline Alley (Sunday strip)

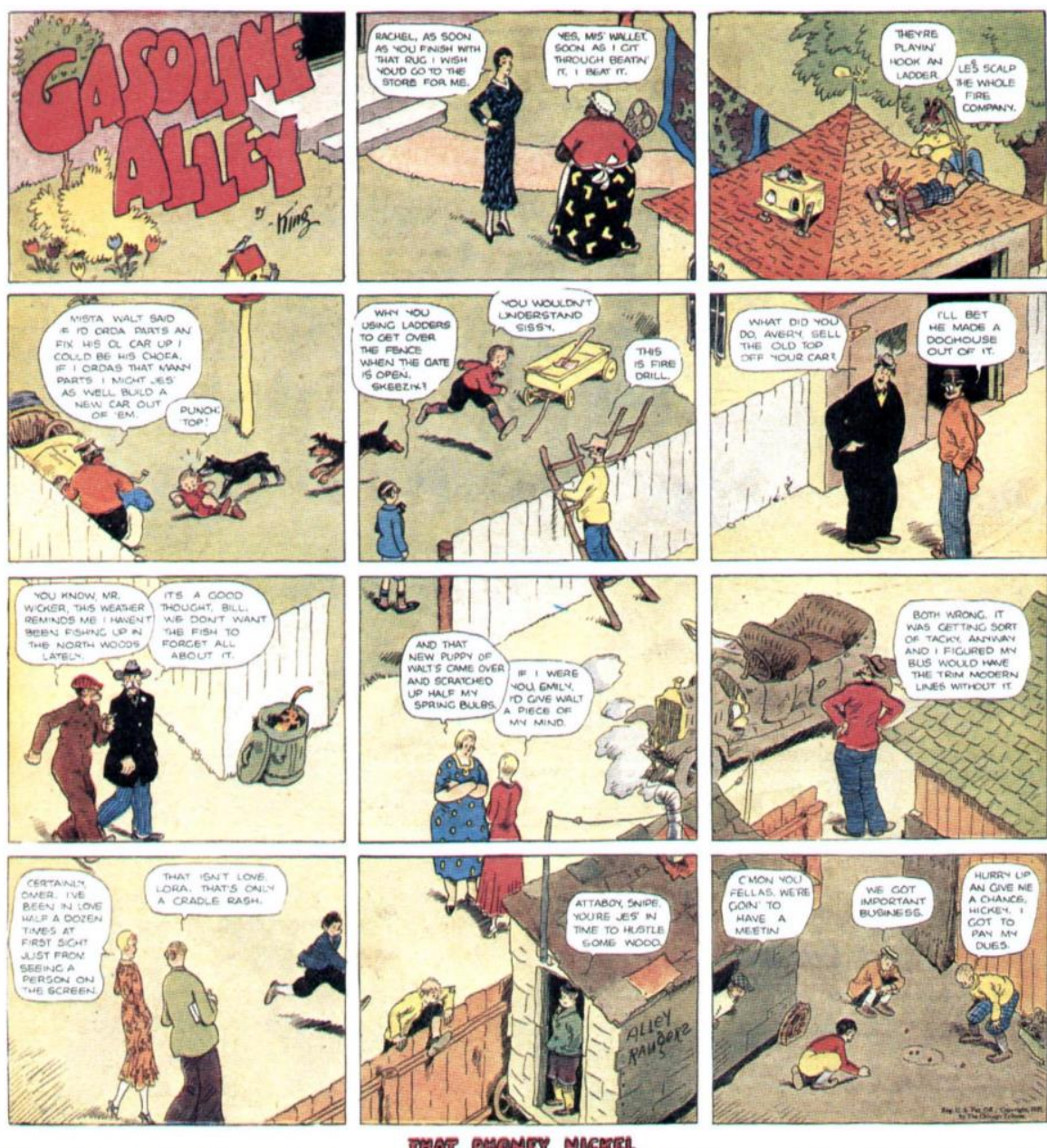

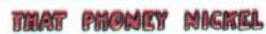

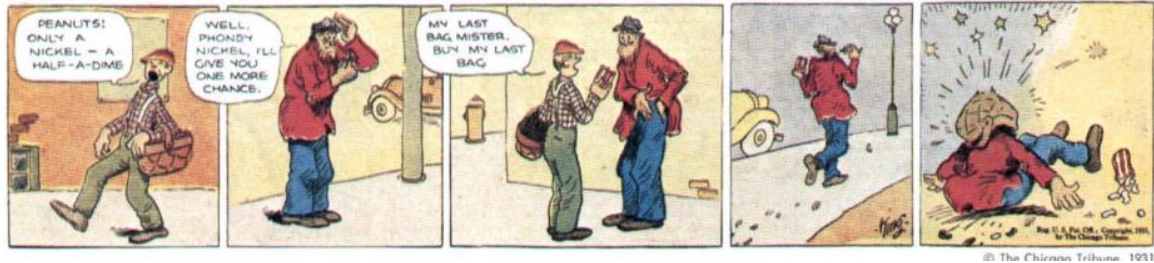

Fonte: Blackbeard e Williams (1977). 
Por fim, ficaram famosas também as tiras dominicais (Figura 5) em que Frank King desenhava um mesmo cenário unívoco (uma praia, uma vizinhança ou a construção de uma casa), separado em requadros, cujo movimento se dava sem que este mesmo cenário se modificasse. Este tipo de dispositivo traz a sensação de que uma parte do quadrinho se mantém estática e outra em movimento, tal qual as distinções entre a imagem simbólica de valor arquetípico (que paira de modo estático) e a imagem onírica freudiana (móvel). Da mesma forma, em um jogo de tarô, um aspecto das imagens (por exemplo, os arquétipos de seus famosos arcanos maiores) se mantém estático, guardando suas características essenciais, e outro parte para a mobilidade (os arcanos menores), considerando a natureza relacional do jogo, sua "máquina" de combinar e de processar dados dos fenômenos, da natureza, da realidade.

\section{Considerações finais}

Logicamente, quadrinhos e tarô são registros distintos de imagens combinadas em série, mas, potencializados pelo movimento difuso, pela temporalidade subjetiva e profundidade de abordagem das imagens (a função intermediária das imagens auráticas), estas duas formas de exprimir o mundo conjugam possíveis lugares de realização da razão poética. Assim, Zambrano (1996) considerava que este tipo de frequência do perceber tem a propriedade de relacionar opostos, trazer sentido ao inexprimível, fazer emergir o incoerente, o impossível.

Talvez seja demais considerar que uma certa análise combinatória das imagens do mundo tenha de fato levado Jodorowsky a encontrar Philippe Camoin e que, a partir de um "jogo de tarô do real", eles tenham sido levados a restaurar o tradicional tarô de Marselha. Mesmo assim, a história costurada por este tipo de sincronicidade (Jung, 1997) nos permite aferir que formas de arte como os quadrinhos de Frank King, com resultados mais visíveis e menos aleatórios, também se balizam em relações profundas presentes no imaginário para produzirem uma densidade semântica que extrapola meras categorias estanques narrativas. Elas reproduzem forças que movimentam os fenômenos, os acontecimentos, em uma latência mais rarefeita e inconsciente. Interessa-nos propor, portanto, uma teoria das artes e das formas de expressão (como o tarô e os quadrinhos) que considere todas estas contingências. 
É certo que as cartas do tarô ainda não são objeto de reflexões sistemáticas no âmbito dos estudos da linguagem, das imagens, da comunicação ou da arte e que não há grandes espaços concedidos a esse tipo de objeto no mundo acadêmico, embora amplo uso seja feito desse tipo de jogo ao longo da história e nas mais diversas civilizações. A aproximação do tarô com as imagens das histórias em quadrinhos apresenta a vantagem de colocar todo um aparato teórico advindo dos estudos de Linguagem, dos estudos em Comunicação e das teorias estéticas a serviço da compreensão do jogo enquanto mídia e enquanto medium na perspectiva da comunicação oracular.

Ademais e por fim, lançamos aqui as bases para uma aplicação da razão poética ao estudo dos fenômenos relacionados ao que Didi-Huberman (2011) chamou de um "gaio saber inquieto". Fenômenos que congregam os saberes de um tipo de visão que antecede a escrita ao mesmo tempo em que a ultrapassa e convive com ela. Saberes populares, saberes ancestrais, saberes primitivos, saberes de uma cultura midiática ou de uma cultura pop, baseados em uma linguagem imagética que não se limita a códigos e sistemas de significação, mas estende seu alcance a toda uma potência latente e atuante naquilo que foi aqui considerado como a dimensão aurática das imagens-sonho.

\section{Referências}

ALTMAN, R. A theory of narrative. New York: Columbia University Press, 2008.

BELTING, H. Pour une anthropologie des images. Paris: Gallimard, 2009.

BLACKBEARD, B.; WILLIAMS, M. (Org). The Smithsonian collection of newspaper comics. Washington: Smithsonian Institution Press, 1977.

CAMPOS, R. Imageria. O nascimento das histórias em quadrinhos. São Paulo: Veneta, 2015.

DIDI-HUBERMAN, G. O que vemos, o que nos olha. São Paulo: Ed. 34, 2010.

Atlas ou le gai savoir inquiet. Paris: Minuit, 2011.

Prefácio. In: MICHAUD, P-A. Aby Warburg e a imagem em movimento. Trad. de Sibylle Muller. Rio de Janeiro: Contraponto, 2013.

DRAVET, F. Entrever no (in)visível: imaginação, comunicação oracular e potência criativa. ECompós, v. 22, n. 1, 29 ago. 2019.

DURAND, G. A imaginação simbólica. São Paulo: Cultrix, 1964. 
DURAND, G. O imaginário: Ensaio acerca das ciências e da filosofia da imagem. Rio de Janeiro: Difel, 2004.

FARLEY, H. A cultural story of tarot: from entertainment to esotericism. London/New York: I.B.Tauris \& Co Ltd, 2009.

FRESNAULT-DERUELLE, P. Récits et discours par la bande. Essais sur les comics. Paris: Hachette, 1977.

FREUD, S. A interpretação dos sonhos. Tradução de Walderedo Ismael de Oliveira. Rio de Janeiro: Imago, 2001.

FREUD, S. Escritores criativos e devaneio. Edição standard brasileira das obras psicológicas completas de Sigmund Freud. Tradução de Maria Aparecida Moraes Rego. Rio de Janeiro: Imago, 1996. v. 9.

GAUDREAULT, A; JOST, F. A narrativa cinematográfica. Tradução de Ciro Inácio Marcondes, Adalberto Müller e Rita Jover-Falleiros. Brasília: UnB, 2009.

GROENSTEEN, T. The system of comics. Trad. do francês para o inglês de Bart Beaty e Nick Nguyen. Jackson: University of Mississippi Press, 2007.

HEER, J. “Introduction”. In: King, F. O. Walt \& Skeezyx. 1927 \& 1928. Montreal: Drawn \& Quartely, 2010.

HUCHET, S. Passos e caminhos de uma teoria da arte. Prefácio à edição brasileira. In: DIDIHUBERMAN. O que vemos, o que nos olha. São Paulo: Ed. 34, 2010.

JODOROWSKY, A.; COSTA, M. A caminho do tarot. São Paulo: Campos, 2016.

JUNG, K.G. Sincronicidade. São Paulo: Vozes, 1997.

KING, F. O. Walt \& Skeezyx. 1927 \& 1928. Montreal: Drawn \& Quartely, 2010.

MAFFESOLI, M. Elogio da razão sensível. Trad. Albert Christophe Migueis Stuckenbruck. Petrópolis, RJ: Vozes, 1998.

MCCLOUD, S. Desvendando os quadrinhos. Tradução de Helcio de Carvalho e Marisa Nascimento Paro. São Paulo: M. Books do Brasil, 2005.

MICHAUD, P-A. Aby Warburg e a imagem em movimento. Trad. de Sibylle Muller. Rio de Janeiro: Contraponto, 2013.

MORIN, E. O método 3. O conhecimento do conhecimento. Porto Alegre: Sulina, 2010.

NICHOLS, S. Jung e o tarô. Uma jornada arquetípica. Trad. de Octavio Mendes Cajado. São Paulo: Cultrix, 1995.

NICOLESCU, B. Contradição, lógica do terceiro incluído e níveis de realidade. 2009. Disponível em: http://www.emse.fr/aslc2009. Acesso em: 26 maio 2020. 


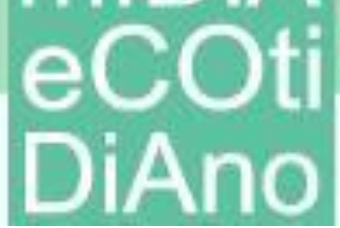

SOSTERIC, M. A sociology of tarot. Canadian Journal of Sociology. n 39, vol. 3, 2014. pp. 357-392.

STAIGER, E. Conceitos fundamentais da poética. Tradução de Celeste Aída Galeão. 3. ed. Rio de Janeiro: Tempo Brasileiro, 2007.

WARBURG, A. Atlas Mnemosyne. Madrid: Akal, 2010.

WEBER, M. A ética protestante e o espírito do capitalismo. São Paulo: Cia das Letras, 2004.

ZAMBRANO, M. Filosofía y poesía. Cidade do México: FCE, 1996. 